\title{
An Analysis of Hester's Hypocrisy in The Scarlet Letter
}

\author{
Yanxia Sang \\ Basic English Department, Dezhou University, Dezhou City, Shandong, China \\ Email: dz_syx@126.com
}

\begin{abstract}
The paper mainly analyzes the hypocrisy of Hester Prynne, the heroine of the famous novel, The Scarlet Letter. Hester was punished because she was found guilty of adultery. She would wear the letter " $A$ " forever, she knew the meaning of the letter " $A$ ", she believed that it wasn't punishment, as she couldn't rebel in public, so she kept silence, she never raised her head to greet other people, if they greeted her, she laid her finger on the scarlet letter and walked away. The letter " $A$ " was artistically done in fine red cloth surrounded by rich gold thread that wasn't in accord with her clothes. As a rebel to the moral, she often thought about the role of a woman in the society. She thought that the system of society must be destroyed and built again long ago, yet she seemed to be always obedient and did so many good things to help others. But under the cover of it, the pride, sneer and rebellion were hidden. She hated the letter "A", but wearing it all the time. Some other actions and thoughts of Hester putting her deep-going thoughts and her seeming obedience together, leads readers to think of her hypocrisy. The difference between her real and disguised aspect proved her hypocrisy.
\end{abstract}

Index Terms-Hester Prynne, hypocrisy, obedience

\section{INTRODUCTION}

The Scarlet Letter tells a single but very moving story in which four people living in a Puritan community are involved in and affected by the sin of adultery in different ways. As she was the heroine of the famous novel the Scarlet Letter by American writer Nathaniel Hawthorne, She is always thought as honest, she is always wearing the letter "A" that means adultery. But since she was punished on that platform, when she touched the scarlet letter " $\mathrm{A}$ " with her finger, she realized that the shame was real and all that in her life was gone, she did many good things to help others and kept silence, so she was always obedient and felt shame with that she had done? No, the differences between her real and disguised aspect proved her hypocrisy. You can make that conclusion by a lot of evidence, such as the beautiful letter "A", her attitude towards her partner Dimmesdale and so on. The main thesis of paper is about Hester's hypocrisy. We should devote us to the faithful life and be far away from the hypocrisy. We should be faithful for the whole life, not stop in the half. To real honest one, we should respect others and ourselves.

\section{THE WRITER'S BACKGROUND KNOWLEDGE OF THE SCARLET LETTER}

\section{A. A Brief Introduction of The Scarlet Letter}

Imbued with an inquiring imagination, an intensely meditation mind, and unceasing interest in the "interior of the heart" of man's being, Nathaniel Hawthorne (1804 1864) remains one of the most interesting, yet most ambivalent writers in the American literary history.

The Scarlet Letter, regarded as the best of his works, tells a simple but very moving story in which four people living in a Puritan community are involved in and affected by the sin of adultery in different ways.

Hawthorne's remarkable sense of the Puritan past, his understanding of the colonial history in New England, his apparent preoccupation with the moral issues of sin and guilt, and his keen psychological analysis of people are brought to full display in his masterpiece, The Scarlet Letter. In this particular novel, Hawthorne does not intend to tell a love story nor a story of sin, but focuses his attention on the moral, emotional, and psychological effects or consequences of the sin on the people in general and those main characters in particular, so as to show us the tension between society and individuals. "The Custom--House", an introductory note to The Scarlet Letter, proves fruitful to Hawthorne's imagination. By relating his own experience of discovering a small package that contains a piece of red cloth shaped like "A" when he was a surveyor in the Custom House in Salem, Hawthorne succeeds in giving his tale a sense of historical reality and air of authenticity, and demonstrates fully his artistic pursuit and his theory about "Romance".

As a man of literary craftsmanship, Hawthorne is extraordinary. The structure and the form of his writings are always carefully worked out to cater for the thematic concern. With his special interest in the psychological aspect of human beings, there isn't much action, or physical movement going on in his works and he's good at exploring the complexity of human psychology. So his drama is thought, full of mental activities.

Hawthorne is a master of symbolism, which he took from the Puritan tradition and bequeathed to American literature in a revivified from. The symbol can be found everywhere in his writing, and his masterpiece provides the most conclusive proof. By using Pearl as a thematic symbol of all, Hawthorne emphasizes the consequence, the sin of 
adultery, has brought to the community and people living in that community. With the scarlet letter "A" as the biggest symbol of all, Hawthorne proves himself to be one of the best symbolists. As a key to the whole novel, the letter "A" takes different layers of symbolic meaning as the plot develops, but people come up with different interpretation and they do not know which one is definite. The scarlet letter " $\mathrm{A}$ " is ambiguous. And the ambiguity is one of the salient characteristics of Hawthorne's art.

\section{B. The Most Hypocritical Character in The Scarlet Letter}

Hester Prynne is the heroine of the famous novel The Scarlet Letter by American writer Nathaniel Hawthorne. In the $19^{\text {th }}$ century, she is not only thought honest by herself, but also by most of the readers out of America. But in fact, the most hypocritical person is nobody but Hester Prynne. There are some differences between what she appears intentionally and what she really is. There are some differences between her real and the outwards aspect. Hester had been found guilty of adultery and was being a mother because of impulse.

Apparently, she rebuilds her reputation at last and gained people's trust and respect step by step because she is brave to admit her guilt. But it's not difficult to know that the scarlet letter A, which has been wearing on, because of standing for adulteries, is no more than a kind of pretence. Under the pretence or penitence, the pride, sneer and rebellion were hidden, as it is very important in understanding Hester's hypocrisy.

\section{The Reason of her Becoming Guilty}

Of course, Hester is a victim who could arouse readers' sympathy. She married an old scholar whom she didn't love. Two years ago, the husband had sent his wife alone across the ocean to the Massachusetts colony, but his ship has never been heard of again. In such situation, Hester, a young attractive widow was found guilty of adultery. Such crime was exposed before the public and she was punished to wear the scarlet letter "A" standing for humiliation all her life. But now we are not going to discuss the revivification and seriousness but the attitude that Hester held to face her fault and punishment.

People can't help asking a question: Hester is not the only one to hide the truth. Why do you think her--the most hypocritical person in The Scarlet Letter? Really, in his novel, Hawthorne explored the hypocrisy of the social morality and the cheat of the religion in America by showing us the portrait of Arthur Dimmesdale and description of the partisans in that period. However, comparative to speak, Hester's hypocrisy is more serious. This is because her disguise cannot be told and found by others easily.

\section{HESTER'S DEEP THOUGHTS}

In order to know Hester's hypocrisy, it's very necessary to know the different meaning of "shame" and "compunction". The former emphasizes the relation between an individual and the outward, but the latter emphasizes the inmost world of individual. When a person thinks that he broke the rules or orders and disgraced himself of his relatives, he always feels ashamed. In such circumstances, he will regulate himself, as the society or others requires. If what he did doesn't betray the law or morals apparently, he will feel easy.

On the contrary, he will be tortured not only with the mistake in public and disgrace caused by his mistake, but also with the fault that no one knows and the potential probability to commit a crime. Such person will feel upset in his heart even though no one blames him.

\section{A. Shame and Compunction}

People always feel uneasy, but the former is because they lose their face in public, while the latter is because the person always blames himself in his heart. A real regretted person should not only suffer from loss in public, but also suffer from the torments of shame in his inmost thought.

\section{B. Compunction}

The following three points can prove Hester Prynne's hypocrisy, the relations between her and the scarlet letter "A"--the symbol of adultery, her attitude to her partner Arthur Dimmesdale, her actions and some other thoughts.

\section{A Real, Honest Regretful Person}

Apparently, the splendor letter sperms to reflect her braveness and to admit her guilt and sad compunction .But on one hand Hester only feels ashamed and disguises to be always obedient and brave to admit her fault. On the other hand, she hates the symbol and the limits of the Puritan Settlement.

From Hester Prynne's first reaction to the scarlet letter "A", we can draw a conclusion that her upsetting comes from: "shame" more than "compunction".

\section{Hester's AtTitude towards The SCARLET LetTER "A" AND DimMESDALE}

When the young woman--the mother of her child fully revealed before the crowd, it seems to be her first impulse to clasp the infant closely to her bosom; not so much by an impulse of motherly affection, as that she might thereby conceal a certain token, which was wrought or fastened into her dress. In a moment, however, wisely judging that one 
token of her shame would but serve to hide blush, and get a haughty smile, and a glance that would not be ashamed, looked around at her towns people and neighbors.

If she feels pain on the way from prison to the market, it's only because that so many people surrounded her and strive to be the first to see her. It seems that her disutility was put in the street and stamped by others; her heart had been flung into the street for them all to spurn and trample upon. When she was forced to stand on a sort of scaffold at the western marketplace, "She felt, at moments, as if she must need shriek out with the full power of her lungs and cast herself from the scaffold down upon the ground, or else go mad at once". Under the heavy weight of a thousand unrelenting eyes, all fastened upon her and concentrated at her bosom. It was almost intolerable to be borne to poor Hester Prynne. So she had the feelings.

\section{A. The Relations between Hester and the Scarlet Letter "A"}

Hester's attitude to the symbol of sin had never changed from beginning to end; she had never looked on it as symbol of her compunction. Untitled end of her life, she wore the token. Although when anyone looked curiously at the scarlet letter and she would sacred refrains, she always did refrains from covering the symbol with her hand. In spite of it, Hester's pain comes not from the compunction with destroying her soul but from the shame that breaks her heart. For example, when her term of confinement was at an end, to Hester Prynne, the most worrying in the future should be that giving up her individuality, she should become the general symbol at which the preacher, and in which they might vivify and emblematic their ages of frailty and sinful passion.

Thus the young and pure would be thought to look at her, with the scarlet letter fluming on her breast--at her, the child of honorable parents, for her, the mother of a baby, and she would be a real woman. She even wouldn't tell the truth of scarlet letter "A" to her daughter--little Pearl, though she was eager to get the sympathy from her letter and her daughter. So when Pearl asked her why she wore the letter and what it meant, Hester answered that she wore it for the sake of its gold thread.

The most important evidence to show her attitude to the letter should be the forest meeting Hester Prynne and her partner Arthur Dimmesdale, a clergyman, when she persuaded Dimmesdale successfully to leave the suffering place with her together. Hester said that "Let us not look back. The past is gone". Let's try to think that if Hester really felt regret and regarded the scarlet letter as the symbol of her compunction, or the reason that she wore the token is not to disguise to obey submissively and repent and turn over the new leaf, but to give it a certain meaning and follow it, she wouldn't hate the scarlet letter so much and give up the symbol and her past which the token stood for so easily.

\section{B. Her Attitude towards her Partner--Dimmesdale}

We can also know Hester's hypocrisy from the attitude that Hester held towards Dimmesdale. Someone believes that the reason why she refuses to tell her partner's name is that she hoped her partner could be saved. But the idea can't hold water. Hester's thought and behavior about Dimmesdale ran in the opposite direction to her disguised honest appearance and tempted the other crime to be hypocritical in return to relive his errors and mend his ways. Hester's silence seemed to show that she would rather suffer the pain alone. But if she didn't tell the truth, she regretted that honest expression would never be sincere. In addition, her later behavior made it clear that she had ulterior motives.

Hester was not only unwilling to tell the name of her partner, but also promise her former husband, Roder Chillingworth, never to disclose his real status because Chillingworth guaranteed that he would do any harm to the criminal reputation, status and his life but ruin his heart or soul as revenge if Hester kept the secret. We can see that, to herself or to her partner, what she cared about most was not soul's rescue but only the reputation, an infect of life, of course, led Chillingworth to offend a saint, she regretted very much and tried too smooth over the fault. But even at that time, what she cared for really was the mental and physical sufferings on her lover but not his soul's permanent sawing because the way she took to end, Dimmesdale and her shame and pain are to escape.

Now people will ask: what's her real motivation to conceal her lover's name and staying place, since her condemnation didn't rescue her within the limits if the Puritan Settlement, so remote and obscure Colony. She could be free to her birthplace, or to go to any other place and hide her character and identity under a new exterior, as completely as if emerging into another state of being. Sufficiently, she said to herself, "Here had been the scene of her guilty, and she should be the torture of her daily shame would work out another purity than that which she had lost".

Hester was cheating herself. The real motive that kept her the scene and pathway that had been so fatal was that "There dwelt, there trodden the feet of one with whom she deemed herself connected in a union, that unrecognized on earth, would bring them together before the bar of final judgment". In another word, Hester had never regretted. She had in her nature arch, voluptuous, oriental characteristic. So she committed the sin. After receiving the punishment, she hid her sinful desire at the bottom of her heart. It seems that she had regretted already but once there is a chance: She would also let the depressed feeling out to commit a crime again.

\section{Hester's Other Actions and Thoughts with her Seeming Obedience.}

We can know about Hester's hypocrisy from behaviors and thoughts. For example, she was good at handwork. To Hester Prynne, the delicate toil of the needle, "might have been a mode of expressing and therefore smoothly, the passion of her life like all other joys, she rejected it as a sin" just as the author pointed out that: This morbid meddling of conscience with an immaterial matter betokened, it's to be feared, no genuine and steadfast penitence, but something 
doubtful, something that might be deeply wrong, beneath. Another example, Chillingworth won the hand of Hester but he had never won the utmost passion of her heart. It led Hester to be a victim. However, Hester ought long ago to have done with such injustice. But even so many years later, Hester still took it in heart and believed that it was Chillingworth that did her wrong. "He had done me worse wrong than I did him!" People cant' help asking, "What did it be token? Had seven long years, under the torture of the scarlet letter, inflicted so much of misery, and wrought out no repentance."

Needless to say that Hester began to hold herself a loaf from the out world but with good intentions towards others in the saying of sin. She took care of patients, helped the poor and comforted the suffering people on her own. But the kind behavior cannot replace the honest or real regret. Or Dimmesdale who was famous for devoutness and his good action would not suffer the pain of compunction and die finally.

Hester's thought also reflected her hypocrisy. Doubtlessly to see, some unknown thought so quite reasonable, for example, her ideas on women's social position and relationship between men and women, the ideas are audacious in the extreme, even sinful in the eyes of the Puritans. Her analysis on other's hidden crime was also quite correct and deep. She realized that if the truth was everywhere to be shown a scarlet letter would blaze forth on many a bosom besides herself. All in all, Hester's some ideas and thoughts are admirable and appraisable, but if we put them with Hester's seemingly honest appearance and her behavior in trying to obey the rules that she was disguised together, some of her superficial belief and the nature of her behavior are abundantly revealed.

\section{CONCLUSION}

An ignorant person who follows all kinds of rules and orders blandly can be forgiven. But Hester can't be forgiven because Hester's deep thoughts forced readers to think that her seeming obedience and appearance is hypocritical.

One of the enlightenment the author wanted to tell us is that "Be true! Be true! Be true! Show freely to the world, if not your worst, yet some trait whereby the worst may be inferred!" However, it's uneasy to be honest for a comment person. In this paper, we analyzed Hester Prynne's hypocrisy generally. From the above analysis we can draw a conclusion. But more important is that we can tell or distinguish clearly what is the seeming honest and what is the real honest.

From this great novel, we should pay much attention to the real honest. To real honest one, we should respect others and ourselves. What's more, it's important to keep us identically, no matter how serious situation we'll meet. Maybe we always help others in the free time, and what's the real reason?

If we were Hester, how can we deal with ourselves? Hester helped others and looked more obedient but in her mind, there were guilt and adultery. To be frank, she is not a real honest one.

It's most important to face us in the life. If we're known that faithfulness is the first reputes, we should be faithful for the whole life, not in half. Otherwise, we'll cover the hypocritical mask and be punished by the moral court at last. Please devote us to the faithful life and be far away from the hypocrisy.

\section{REFERENCES}

[1] Stauffer, Donald. collected. (1992). Novels of America. Now York: Graw-Hill Book Company.

[2] Ravenel, Shannon. (1997). The Best American Novels of $19^{\text {th }}$ Century. Boston: new American Library.

[3] Nathaniel Hawthorne. (1990). The Scarlet Letter. Boston: Houghton Mifflin Company.

[4] Bradley, Sculley, ed. (1968).The Scarlet Letter: An Annotated Text Background s and Sources Essay s in Criticism. Cambridge \&London: The MIT Press.

[5] Joseph, Bristow, and Thomas Wortham, eds. (1999). Nineteenth-Century Literature. Vo 1. 54, No. 3. University of California Press.

Yanxia Sang was born in Dezhou city, Shandong Province, China in 1976. She received her M.A. degree in linguistics from Shandong University, China in 2008.

She is currently a lecturer in Basic English Department, Dezhou University, Dezhou city, Shandong Province, China. Her research interests include English and American literature. 